\title{
Environmental factors influencing the seasonal daily activity of the European rabbit (Oryctolagus cuniculus) in a Mediterranean area
}

\author{
by R. VILLAFUERTE', M.B. KUFNER ${ }^{2}$, M. DELIBES ' and S. MORENO' \\ 'Estación Biológica de Doñana. C.S.I.C. Apdo. 1056. 41080. Sevilla. España. \\ 'Universidad Nacional de Córdoba, Fac. Ciencias Exactas. \\ Físicas y Naturales. Córdoba, Argentina
}

Summary. - Activity pattern of European wild rabbits has been studied in a Mediterranean ecosystem of SW Iberian Peninsula, from where they are a native species. The daily activity pattern of rabbits in the area is similar to those found in other countries where the species has been introduced : high activity at night and at twilights. and scarce activity by day. However, this general pattern shows seasonal changes probably related to environmental conditions and antipredatory strategies. Changes in rabbits activity are correlated mainly with temperature, but sunlight, moonlight. and wind also affectit. Variations of activity pattern suggest that controlling mechanisms are flexible enough to allow adaptations to changing environments.

Résumé. - Le rythme d'activité des lapins de garenne a été étudié dans un écosystème méditerranéen du sud-ouest de la péninsule ibérique, aire d'origine de cette espèce. Le rythme d'activité journalier dans la région est similaire à celui qu'on observe dans d'autres pays où l'espèce a été introduite : activité importante durant la nuit et au crépuscule, mais faible durant la journée. Cependant. ces tendances générales montrent des variations saisonnières probablement relićes aux conditions environnementales et aux stratégies anti-prédateurs. Les changements d'activité des lapins sont corrélés principalement avec la température, mais l'illumination solaire et lunaire l'affectent également. Les variations du rythme d'activité suggèrent que les mécanismes qui le contrôlent sont suffisamment souples pour permettre l'adaptation aux environnements changeants.

\section{INTRODUCTION}

The European rabbit, Oryctolagus cuniculus, originated from the Mediterranean Basin (Zeuner 1963, McBride 1988), where it makes up the base of the vertebrate predator-prey system (Delibes and Hiraldo 1981). From there, the rabbit has been widely distributed by man in Europe and near islands, Chile and Argentina, Australia, New Zealand, and some Oceanic islands (Corbet 1978). Most of the present knowledge about wild rabbit ecology and behaviour has been obtained in areas where it was intro-

Mammalia, t. 57. $n^{\circ} 3.1993$. 
duced (Mykytowycz and Rowley 1958, Howard and Amaya 1975, Wood 1980, Rogers 1981, Gibb et al. 1985, etc), but there lacks information about the species habits in its original range (see, for instance, Gibb 1990). As in their new areas rabbits have adapted to different biotic and abiotic conditions, many aspects of their primitive biology and behaviour may have changed (Flux 1965, Jaksic et al. 1979, Soriguer 1981).

The aim of this paper is to give information about the circadian and seasonal pattern of above ground activity by European rabbits in a Mediterranean area of SW Spain, and relate this pattern of activity to meteorological conditions. It can be thought that rabbits, like other burrowing animals, could avoid a harmful weather by staying in the moderate environment of their warrens (Hayward 1961). Therefore, active time above ground would depend on the weather outside and it could change at different areas. We will try to compare rabbit activity pattern in Mediterranean Spain with those known in other latitudes (e.g. Kolb 1986).

\section{METHODS}

The study was carried out from July 1984 to February 1987, in the Doñana Biological Reserve, SW Iberian Peninsula $\left(37^{\circ} \mathrm{N}, 6^{\circ} \mathrm{W}\right)$. The climate is Mediterranean, with rainy mild winters (January mean temperature $11^{\circ} \mathrm{C}$ ) and hot dry summers (August mean temperature $25^{\circ} \mathrm{C}$ ). Most rainfall takes place from October to February (annual precipitation approx. $550 \mathrm{~mm}$ ). The three main biotopes of the area are dunes, scrubland and marshes, rabbits being especially common in the scrubland and the ecotone between the scrubland and the marshes. Additional information about the area can be found in Ales (1986) and Rogers and Myers (1980).

The estimation of rabbit activity was based on the results yielded by 137 rabbit counts from a vehicle driven at a fixed speed $(15 \mathrm{~km} / \mathrm{h})$ along a previously chosen $13 \mathrm{~km}$ long circuit in the scrubland area. Counts were made four times a day (at sunrise, midday, sunset, in the middle of the night) for three consecutive days, approximately each two months. Midday and midnight counts were carried out within the hour corresponding to the middle ot the light or dark period of the day respectively. A powerful white spotlight $(100 \mathrm{~W}, 12 \mathrm{~V})$ was used for night counts.

Because the structure and composition of the scrub at Donana do not change significantly nor annually nor monthly (Ales 1986), it was assumed that visibility was not different between the same period of the day at different counts.

To quantify activity we assumed that rabbit abundance did not vary within the three days of each monthly sampling period. Therefore, we obtained for each count an index of activity (IA) by dividing the number of rabbits observed at this count by the highest number of rabbits observed at any count of the same sampling period (minimum number of rabbits present at this month).

Twenty environmental variables, 15 of weather and 5 relative to moonlight and sunlight, were considered to analyse their relation to rabbit activity; they are specified in Table 1. Meteorological data were obtained from "Cortijo Los Mimbrales", a climatic station of the Instituto Meteorológico Nacional, situated at about 8 kilometres of the census area. A factor analysis (Dixon 1975) was carried out to group the 20 environmental variables and allowed an easier interpretation of the results. The relationships among weather factors and activity was evaluated by a stepwise regression analysis (Dixon 1975) of the factors resulting from the factor analysis on the IA obtained at each census. 


\section{RESULTS}

Circadian activity. Annual variation.

A two-way ANOVA of activity indices among the years showed no differences $\left(F_{(3.133)}=0.333, p=0.802\right)$, but there were significant differences among the day moments $\left(\mathrm{F}_{(3.133)}=41.978, \mathrm{p}<0.001\right)$, the interaction not being significant $\left(\mathrm{F}_{(9.127)}=\right.$ $1.283, \mathrm{p}=0.253$ ). Thus, in order to create a figure which represented the monthly tendency of the IA along the year, we pooled the results belonging to different years by months (Fig. 1).
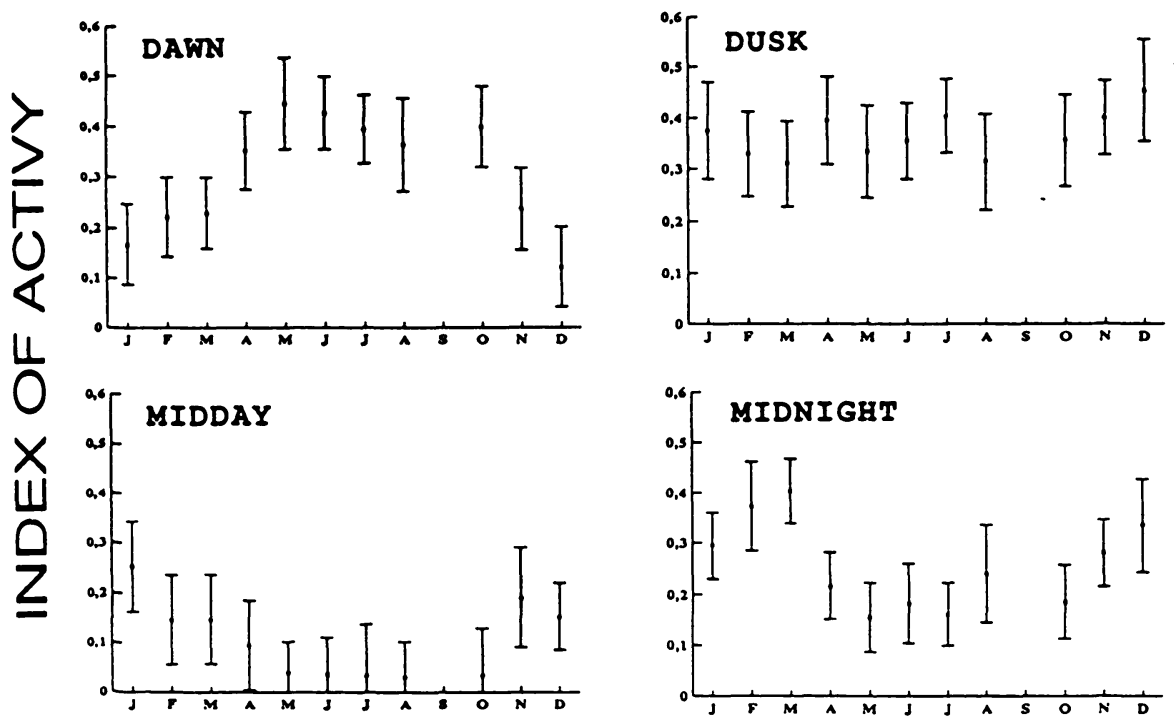

Fig. 1. - Annual variation (mean \pm SE) of the index of activity (IA) of rabbits in the Donana National Park in the four considered daily periods.

As a rule, rabbits in the study area show high activity indices at night $(\overline{\mathrm{x}} \pm \mathrm{SD}=$ $0.261 \pm 0.016, \mathrm{n}=33)$, at sunset $(0.364 \pm 0.012, \mathrm{n}=36)$ and at dawn $(0.304 \pm 0.021, \mathrm{n}$ $=34)$, but they are scarcely active at midday hours $(0.110 \pm 0.017, \mathrm{n}=34)$.

This general activity pattern shows intra-annual fluctuations. The monthly variation of daily activity pattern is represented in Figure 1. Activity at dawn is very low during the winter months, but it progressively increases and reaches the highest values in summer. Although very low all the year round, midday activity shows a peak in winter and becomes practically null in summer. The evening crepuscular activity shows very little variation throughout the year, being consistenly high. At night rabbits show high activity in winter and low in summer, a pattern opposite to that at sunrise.

\section{Influence of the environmental factors on activity.}

Principal component analysis reduced the 20 environmental variables to five, which explain $76 \%$ of the variation in the original environmental data (Table 1). The 
remaining 15 principal components had eigenvalues under 1 and were not considered in further analyses.

The first factor is characterized by the variables of temperature and drought (referred to as "temperature"); the second factor by the brightness of moon ("moonlight"); the third one by the amount of sun illumination ("sunlight"), which also includes air humidity, negatively related to sun height : the fourth by rainfall within 15 days of data collection ("accumulated rain") ; and the fifth by air pressure and wind ("wind").

The multiple regression analysis carried out on the principal component factors and the IA for each day period show different significant correlations (Table 2). Factor

TABLE 1. - Standarized factor coefficient matrix for the first five principal components of the weather data. $\mathrm{R}^{2}$ is the communality of the factors with the original weather variables.

\begin{tabular}{|c|c|c|c|c|c|c|}
\hline \multirow[b]{2}{*}{ VARIABLE } & \multicolumn{5}{|c|}{ FACTORS } & \multirow[b]{2}{*}{$R^{2}$} \\
\hline & I & II & III & IV & $\mathrm{V}$ & \\
\hline Potential Evotranspiration & 0.979 & 0.278 & 0.090 & -0.195 & 0.010 & 0.895 \\
\hline Dally average of remperature & 0.869 & 0.184 & 0.110 & -0.181 & 0.261 & 0.901 \\
\hline Daily maximum temperature & 0.812 & 0.260 & 0.148 & -0.207 & 0.020 & 0.792 \\
\hline Daily minimum temperature & 0.703 & -0.078 & 0.030 & -0.157 & 0.475 & 0.751 \\
\hline Census temperature & 0.657 & 0.108 & 0.472 & -0.065 & 0.223 & 0.712 \\
\hline Amount of rain within the previous 60 days & -0.865 & 0.257 & 0.003 & 0.006 & -0.173 & 0.843 \\
\hline Amount of rain within the previous 30 days & -0.693 & 0.304 & 0.066 & 0.451 & -0.260 & 0.847 \\
\hline Days since ralnfall & 0.666 & 0.170 & 0.111 & -0.314 & -0.224 & 0.633 \\
\hline N1ght lllumination (moon phase/cloudness) & 0.215 & 0.788 & -0.103 & 0.040 & -0.152 & 0.702 \\
\hline Moon phase $(0-15$, new to full respectivelly) & 0.046 & 0.938 & -0.009 & -0.033 & 0.082 & 0.890 \\
\hline Moon time percent at night & -0.005 & 0.918 & 0.042 & -0.050 & 0.099 & 0.857 \\
\hline Daytime illumination (sun helght/cloudness). & 0.084 & -0.012 & 0.865 & -0.007 & 0.068 & 0.759 \\
\hline Sun height & 0.039 & -0.010 & 0.894 & -0.118 & 0.058 & 0.817 \\
\hline Relative munidity & -0.400 & -0.081 & -0.686 & 0.176 & -0.008 & 0.668 \\
\hline Humldity change from former count & -0.037 & -0.090 & 0.623 & 0.106 & 0.204 & 0.451 \\
\hline Amount of rain within the previous 15 days & -0.378 & 0.188 & 0.032 & 0.826 & -0.194 & 0.899 \\
\hline Amuunt of rain within the provious 7 days & -0.266 & -0.071 & -0.028 & 0.880 & 0.005 & 0.850 \\
\hline Amount of rain from the former day & -0.066 & -0.234 & -0.210 & 0.665 & 0.429 & 0.730 \\
\hline Wind velocity & 0.083 & 0.033 & 0.219 & 0.017 & 0.745 & 0.611 \\
\hline Barometric pressure & -0.429 & -0.071 & -0.003 & -0.012 & -0.676 & 0.647 \\
\hline
\end{tabular}

Asterisks show the weather varlables which change in each census, the remaining variables change in each day.

TABLE 2. - Stepwise regression analysis of environmental factors on rabbits activity. ${ }^{*} p<0.05:{ }^{* *} p<0.01$; $* * * p<0.001$.

\begin{tabular}{|c|c|c|c|}
\hline \multirow[b]{2}{*}{ DANA } & \multicolumn{2}{|l|}{$t$-value } & Model \\
\hline & & & \\
\hline Factor I (Temperature) & $4.50^{\cdots}$ & $\begin{array}{l}R^{2}=.387 \\
d f=32\end{array}$ & $\begin{array}{l}F=20.24^{\cdots} \\
S E=6.00\end{array}$ \\
\hline \multicolumn{4}{|l|}{ MIDDAY } \\
\hline $\begin{array}{l}\text { Factor III (Sunlight) } \\
\text { Factor IV (Accumulated rain) } \\
\text { Factor V (Wind) }\end{array}$ & $\begin{array}{l}-3.67 \cdots \\
2.78 \cdots \\
-4.00 \cdots\end{array}$ & $\begin{array}{l}R^{2}=.531 \\
d f=30\end{array}$ & $\begin{array}{l}F=11.30^{\cdots} \\
S E=2.45\end{array}$ \\
\hline \multicolumn{4}{|l|}{ DOSK } \\
\hline \multicolumn{4}{|l|}{ None significant } \\
\hline \multicolumn{4}{|l|}{ MIDNIGET } \\
\hline $\begin{array}{l}\text { Factor I (Temperature) } \\
\text { Factor II (Moonlight) }\end{array}$ & $\begin{array}{c}-3.13^{*} \\
2.16^{\circ}\end{array}$ & $\begin{array}{l}R^{2}=.328 \\
d f=30\end{array}$ & $\begin{array}{l}F=7.33^{\cdots} \\
S E=7.17\end{array}$ \\
\hline
\end{tabular}


I, "temperature", has a statistical relationship with dawn and midnight activities, but with a different sign (positive at dawn and negative at midnight).

"Moonlight " (Factor II) seems to have a positive influence on midnight activity. "Sunlight" (Factor III) and "wind" (Factor V) show negative correlations with activity at midday. At this time, the correlation with "accumulated rain" (Factor IV) is positive. No factor shows statistical relationship with activity at dusk.

\section{DISCUSSION}

Our results show that in SW Spain the above ground activity of rabbits is higher during twilights and night. This pattern is not different from those found in other areas where rabbits have been introduced (Mykytowycz and Rowley 1958, Jilge 1980, Wallage-Drees 1989).

Weather has proved to be an important cause of variation of rabbit activity in all areas where the problem has been studied. In general, rabbits seem to be affected by the same weather factors, although the way they are affected does not always coincide.

In our study area, wind reduces activity, the same tendency that was found for cottontails (Kline 1965), and rabbits (Southern 1940, Rowley 1957). Southern (1940) suggested that feeding activity was decreased by wind, but not by rain. At Donana, the influence of accumulated rain upon activity is only evident at midday. In this semiarid Iberian environment, the after-rain periods are the only favourable moments for plant growth, starting the breeding period for rabbits, and in spite of the high predation risk occurring during the day hours (Kufner 1986), young rabbits take a risk feeding aboveground at this time. In any case, the method here employed does not reflect the possible effect of the different behaviour that rabbits exhibit depending their age (e.g. Vitale 1989).

In Doñana moonlight has a positive statistical relationship with nocturnal activity. This behaviour is opposite to that found for other mammalian prey species (e.g. Lockard and Owings 1974, Alkon and Saltz 1988). Certainly, our results should be taken carefully, as moonlight may allow a higher proportion of active rabbits to be seen. On the contrary, sunlight tends to reduce activity at noon, rabbits being more active on cloudy' day's. The influence of light upon rabbit activity seems to be related with its key position as prey in the Iberian Mediterranean biocenoses (Delibes and Hiraldo 1981). The lack of shadows at cloudy days and at twilight, together with rabbit cryptic colouring and its sight adaptation to low light condition (Nuboer et al. 1983) should minimize predation risk (Lockard and Owings 1974).

Temperature appears to greatly influence activity of rabbits, whose circadian pattern could be modified by thermoregulatory requirements. So, rabbits seem to keep inactive when temperatures are extreme but they are active in mild temperatures. Since usually temperatures at night are higher than at dawn, in the winter months rabbit activity decreases at dawn, despite the favourable light conditions, and increases at night.

In Doñana, the activity level at dusk was not related with any environmental factor. This seems to indicate that dusk could be considered the best of the four day period here considered to carry out rabbit censuses.

In the wild, rabbits must trade off thermoregulatory requirements and other problems related to survival, such as predation risk. The general activity pattern of rabbits in the Mediterranean Basin, their original area, seems to be a compromise between 
antipredatory and thermoregulatory strategies. The rather similar activity pattern found in Mediterranean Iberia and other latitudes suggests that it corresponds to an endogenous timing mechanism. Probably the size and physiology of rabbits allow scarce alternatives of variation to this original pattern. However, rabbits exhibit some flexibility in their activity, being able to adapt themselves to different environmental conditions along the year, along the day or in different regions of the world.

The index of activity has shown to be adequate in this study to show general tendencies and the influence of some environmental factors upon rabbits. In spite of this, the different behaviour exhibited by rabbits depending on breeding season or among age classes or sexes. and not controlled in this study, suggests that further studies using different, and more informative methodologies (as radiotracking techniques) are required.

\section{ACKNOWLEDGEMENTS}

The work was supported by the PB87-0405 and the PB90-1018 (DGICYT). Our thanks are expressed to the following persons for critically reviewing the manuscript : Drs. D. Wood, M. Wallage-Dress, R. Trout, C. de le Court. E. Collado, and an anonymous reviewer.

\section{BIBLIOGRAPHY}

Ales, E.E., 1986. - Cartografia de la vegetación arbórea de la Reserva Biológica de Doñana y. evoluctión del matorral de las arenas estabilizadas. Ms. D. diss., University of Sevilla.

AlkoN. P. and D. SALTZ. 1988. - Influence of season and moonlight on temporal-activity pattern of Indian crested porcupines (Hystrix indica). J. Mamm.. $69: 71-80$.

CORBET, G.B., 1978. - The mammals of the Paleartic Region. A taxonomic review. British Museum (Natural History). Cornell University Press.

Delibes, M. and F. Hiraldo, 1981. - The rabbit as prey in the Iberian Mediterranean ecosystem. Pp. : 614-622. In : Proc. World Lagomorph. Conf. Myers, K. and Mac Innes, C.D. (eds.). Guelph, Canada 1979.

DixON, W.J., 1975. - Biomedical Computer Programs. Calif. Univ. Press. Berkeley.

FLuX, J.E.C., 1965. - Timing of the breeding season in the hare, Lepus europaeus Pallas, and rabbit, Oryctolagus cuniculus (L.). Mammalia, 29 : 557-562.

GiBB, J.A., 1990. - The european rabbit. Pp. : 116-120. In : J.A. Chapman and J.E.C. Flux (eds). Rabbits, hares and pikas. Status survey and conservation action plan.

GiBb, J.A., A.J. White and C.P. WARD, 1985. - Population ecology of rabbit in the Wairarapa, New Zealand. N.Z.J. Ecol., 8 : 55-82.

HAYWARD, J.S., 1961. - The ability of the wild rabbit to survive in conditions of water restriction. CSIRO Wild. Res., $6: 160-175$.

HowARD, W.E. and J.N. AmaYA, 1975. - European rabbit invades western Argentina. J. Wildl. Manage., 39 : 757-761.

JAKSIC, F.M., E.R. FuENTES and J.L. YaÑEZ, 1979. - Spatial distribution of the old world rabbit (Oryctolagus cuniculus) in central Chile.J. Mamm., 60 : 207-209.

Jilge, B., 1980. - Circadian periodicity in the rabbit. Zwierzeta Laboratoryine, 17 : 125-130.

KLINE, P.D., 1965. - Factors influencing roadside counts of cottontails. J. Wildl. Manage.. 29 : 665-671. 
KOLB. H.H.. 1986. - Circadian activity in the wild rabbit (Oryctolagus cuniculus). Mammal Rev., $16: 145-150$.

KUFNER, M.B., 1986. - Tamaño, actividad, densidad relativa y preferencias de hábitats de los pequeños y medianos mamíferos de Doñana, como factores condicionantes de su tasa de predación. Doct. Thesis, Univ. Autonoma Madrid.

LOCKARD. R.B. and D.H. OwINGS, 1974. - Seasonal variation in moonlight avoidance by bannertail kangaroo rats. J. Mamm., $55: 189-193$.

MCBRIDE, A., 1988. - Rabbits and Hares. Oxford Univ. Press. Whittet Books. London.

MYKYTOWYCZ, R. and I. RowLEY, 1958. - Continuons observations of the activity of the wild rabbit, Oryctolagus cuniculus (L.), during 24-hour periods. CSIRO Wildl. Res., 3 : 26-31.

Nuboer. J.F.W.. W.M. VAN NuYS and J.C. VAN Steenberger. 1983. - Colour changes in a light regimen as synchronizers of circadian activity. J. Comp. Phy:siol., $151: 359-366$.

Rogers. P.M., 1981. - The wild rabbit in the Camargue, southern France. Pp. 587-599. In: Proc. World lagomorph. Conf. Myers, K. and MacInnes. C.D. (eds.). Guelph, Canada 1979.

Rogers. P.M. and K. MYers. 1980. - Animal distributions, landscape classification and wildlife management, Coto Doñana, Spain. J. Appl. Ecol., 17 : 545-565.

ROWLEY. I., 1957. - Observations on evening rabbit activity in relation to weather and sunset. CSIRO Wildl. Res., 2 : 168-169.

Sorigler. R.C.. 1981. - Biología y dinámica de una población de conejos (Oryctolagus cuniculus, L.) en Andalucía occidental. Doñana Acta Vert.. $n^{\circ}$ esp.. 8, 379 pp.

SOUTHERN, H.N., 1940. - The ecology and population dynamics of the wild rabbit (Oryctolagus ('uniculus). Ann. App. Biol., 27 : 509-526.

VITALE. A.F.. 1989. - Changes in the anti-predator responses of wild rabbits. Oryctolagus cuniculus (L.), with age and experience. Behaviour, $110: 47-61$.

WALLAGE-DRESS. J.M., 1989. - A field study on seasonal changes in the circadian activity of rabbits. Z. Säugetierk., 54 : 22-30.

WooD. D.H., 1980. - The demography of a rabbit population in an arid region of New South Wales. Australia. J. Anim. Ecol., 49 : 55-79.

ZEUNER. F.E.. 1963. - A history of domesticated animals. London, Hutchinson. 
Brought to you by | Est Biologica de Donana (Est Biologica de Don Authenticated | 172.16.1.226

Download Date | 6/6/12 9:31 AM 